\title{
Early experience with cap-assisted endoscopic pancreatic necrosectomy: A technique to enhance safe tissue extraction and decrease interventions
}

\section{다)(i) $\odot=$}

\author{
Authors \\ Nishant Puri, Alexander Hallac, Wichit Srikureja \\ Institution \\ Providence Gastroenterology, Spokane, Washington, \\ United States
}

submitted 10.9.2018

accepted after revision 16.3.2019

\section{Bibliography}

DOI https://doi.org/10.1055/a-0918-5772 |

Endoscopy International Open 2019; 07: E912-E915

(c) Georg Thieme Verlag KG Stuttgart · New York

eISSN 2196-9736

Corresponding author

Nishant Puri, MD, FACP, FACG, Providence Gastroenterology

- South, 105 W. 8th Avenue, Suite 7050, Spokane,

WA 99204

Fax: +1-509-227-7070

npurigi@gmail.com

\section{ABSTRACT}

Background and study aim Endoscopic treatment of walled-off pancreatic necrosis (WOPN) has been estab- lished as an alternative to operative intervention for well selected patients for many years.

Patients and methods A retrospective database of patients who underwent cap-assisted endoscopic necrosectomy of symptomatic or infected WOPN using the assistance of a sterilized banding cap was constructed. All procedures were performed at a single center between January 2017 and June 2018.

Results Eight patients met the inclusion criteria for this study. Contrast computed tomography scan was obtained between the initial percutaneous or trans-gastric access and initial necrosectomy. The WOPN had a median length of $9.5 \mathrm{~cm}$ (range $3.2-14$ ) and width of $5.3 \mathrm{~cm}$ (range 2.8 11.6). Median duration of endoscopic debridement was 69 minutes (range $21-105$ ). Four of six patients underwent a second debridement with a median duration of 95 minutes (range 16-108). No periprocedural adverse events occurred. Follow-up was at 6 months, and there were no additional endoscopic or percutaneous interventions for recurrent pancreatic fluid collections.

Conclusion The technique of cap-assisted necrosectomy can allow for safe and efficient method of endoscopically treating WOPN.

\section{Introduction}

Acute pancreatitis is the third most common gastrointestinal diagnosis leading to hospital admission in the United States [1]. The spectrum of disease ranges from mild, self-limiting edema of the pancreas to severe necrotizing pancreatitis, which is life-threatening and requires thoughtful interventions. Approximately $80 \%$ of cases of acute pancreatitis are mild and the remainder will develop necrosis, with secondary infection occurring in $30 \%$ of those patients [2-4].

Endoscopic therapy for walled-off pancreatic necrosis (WOPN) was initially performed by Barron in 1996 and is widely referred to as pancreatic necrosectomy [5]. Since the inception of the endoscopic ultrasound (EUS)-guided transgastric approach, stent technology has advanced from plastic doublepigtail stents to fully-covered metal stents and currently Lu- men-apposing metal stents (LAMS) [6,7]. LAMS facilitated the popular "through-the-stent" technique. Use of LAMS facilitates creation of a cyst-gastrostomy, allowing for same-session and subsequent endoscopic necrosectomy [8].

Prior to the advent and development of endoscopic necrosectomy, surgical necrosectomy was the only option despite being associated with significant morbidity. The surgical approach has also undergone an evolution to a video-assisted retroperitoneal dissection, which continues to carry significant morbidity, up to $6.8 \%$ in North America [9].

Endoscopic necrosectomy is less morbid than the surgical approach for carefully selected patients, but is subject to complications. It typically uses available endoscopic tools to attempt to remove the infected necrosum; however, these tools are not ideal and often lead to lengthy procedures. 
Despite the increase in incidence of acute pancreatitis and demonstration of decreased hospital stays in patients who underwent endoscopic rather than surgical necrosectomy, there has not been any development of endoscopic tools to increase the yield of endoscopic tissue requisition [10]. A novel technique of cap-assisted necrosectomy was recently described by the author (N.P) and we now present this case series, detailing our experience utilizing banding caps to assist with endoscopic pancreatic necrosectomy [11].

\section{Patients and methods}

The IRB approved creation of a retrospective database of all patients that underwent cap-assisted necrosectomy for infected or symptomatic WOPN. All cases since the report of the approach in 2017 were included [11]. Eight patients were identified who underwent endoscopic ultrasound (EUS)-guided through-the stent endoscopic pancreatic necrosectomy. Baseline demographic data (age, gender, body mass index [BMI]) were collected, as well as information on the etiology and presence of infection. Details about all endoscopic interventions, including duration and utilization of LAMS, were collected. Radiologic studies and interventions performed after diagnosis of acute pancreatitis were reviewed to assess the treatment response of the WOPN. The Charlson score, a prospectively-validated assessment of comorbidity, was calculated for each patient to illustrate pre-procedure health [12]. The procedures were performed by two experienced endoscopists (N.P. and
W.S.) at a single institution. All endoscopic interventions happened a minimum of 4 weeks after onset of pancreatitis as is recommended by the American Society for Gastrointestinal Endoscopy (ASGE) [7].

\section{Technical methods}

Details of the technique used for these cases were published in a recent article [11]. EUS-guided cyst-gastrostomy was performed with a cautery-enhanced lumen-apposing metal stent (LAMS), $15 \mathrm{~mm} \times 10 \mathrm{~mm}$ (Axios, Boston Scientific, Natick, Massachusetts, United States). Interventional Radiology-guided drains were placed in patients who did not have mature WOPN while awaiting EUS-guided access. EUS-guided trans-gastric access was performed prior to endoscopic debridement or in conjunction with the first debridement.

The WOPN was entered through the LAMS, after an initial debridement, a sterilized banding cap (6 shooter multiband ligator, Cook Medical, Bloomington, Indiana, United States) was attached to the endoscope to apply suction from the stent lumen, which facilitated increased retrieval of necrotic material ( $\triangleright$ Fig.1). While the cap was kept within the lumen of the stent, a snare was opened, necrotic tissue was suctioned, and the snare was used to either cut or pull away the necrotic debris. Similarly, the raptor forceps were opened within the cap and suction was applied. This facilitated safe and efficient removal of large pieces of necrosum. Follow-up CT scans were done in 4 to 6 weeks to confirm resolution of the WOPN. If there was resolution, the LAMS was endoscopically removed.
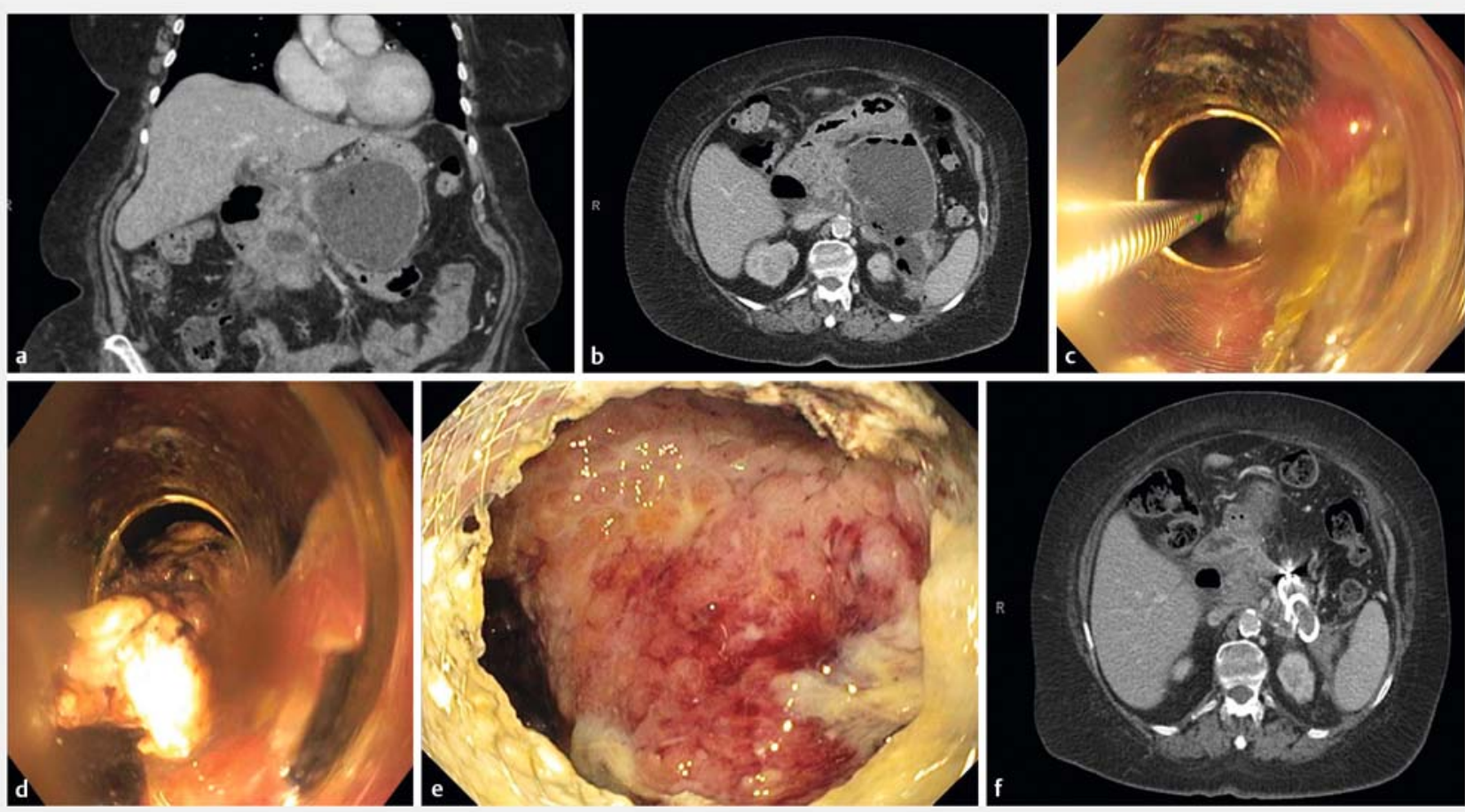

- Fig. 1 a, b Initial CT scan showing walled-off pancreatic necrosis (coronal and sagittal views). c Large tissue pieces removed with capassisted snare. $\mathbf{d}$ Necrotic tissue removed by suction through a transparent banding cap. e endoscopic view of pancreas after necrosectomy. f Post-cap-assisted necrosectomy CT scan demonstrating resolution of walled-off pancreatic necrosis. 
- Table 1 Patient and pancreatitis characteristics

\begin{tabular}{|c|c|c|c|c|c|c|c|c|c|}
\hline $\begin{array}{l}\text { Pa- } \\
\text { tient }\end{array}$ & $\begin{array}{l}\text { Age } \\
\text { (Years) }\end{array}$ & $\begin{array}{l}\text { BMI, } \\
\mathrm{kg} / \mathrm{m}^{2}\end{array}$ & $\begin{array}{l}\text { Gen- } \\
\text { der }\end{array}$ & $\begin{array}{l}\text { Etiology } \\
\text { of pan- } \\
\text { creatitis }\end{array}$ & $\begin{array}{l}\text { Carlson } \\
\text { comor- } \\
\text { bidity } \\
\text { index }\end{array}$ & $\begin{array}{l}\text { Presence } \\
\text { of chron- } \\
\text { ic pan- } \\
\text { creatitis }\end{array}$ & $\begin{array}{l}\text { Interval be- } \\
\text { tween acute } \\
\text { pancreatitis } \\
\text { and first en- } \\
\text { doscopic in- } \\
\text { tervention } \\
\text { (Months) }\end{array}$ & $\begin{array}{l}\text { CT scan meas- } \\
\text { urement of } \\
\text { WOPN prior } \\
\text { to endoscopic } \\
\text { necrosectomy } \\
\text { (length } \times \text { width } \\
\text { [cm]) }\end{array}$ & $\begin{array}{l}\text { WOPN status at } \\
\text { follow up CT scan } \\
\text { (days since final } \\
\text { necrosectomy) }\end{array}$ \\
\hline 1 & 77 & 23 & M & $\begin{array}{l}\text { Gallstone/ } \\
\text { post pro- } \\
\text { cedure }\end{array}$ & 5 & No & 13 & $9.5 \times 5.0$ & Resolved, 22 days \\
\hline 2 & 65 & 27 & M & Idiopathic & 4 & No & 4 & $9.5 \times 5.6$ & $\begin{array}{l}\text { Decreased, } 15 \text { days } \\
\text { later } \\
\text { Resolved, } 110 \text { days }\end{array}$ \\
\hline 3 & 26 & 40 & $\mathrm{~F}$ & $\begin{array}{l}\text { Gallstone/ } \\
\text { post pro- } \\
\text { cedure }\end{array}$ & 0 & No & 8 & $3.2 \times 2.9$ & $\begin{array}{l}\text { Decreased, } 37 \text { days } \\
\text { Resolved, } 66 \text { days }\end{array}$ \\
\hline 4 & 73 & 25 & M & $\begin{array}{l}\text { Alcohol } \\
\text { induced }\end{array}$ & 3 & No & 2 & $12.3 \times 11.6$ & Resolved, 34 days \\
\hline 5 & 41 & 32 & M & $\begin{array}{l}\text { Alcohol } \\
\text { induced }\end{array}$ & 3 & Yes & 4 & $9 \times 2.8$ & $\begin{array}{l}\text { Decreased, } 46 \text { days } \\
\text { Resolved, } 52 \text { days }\end{array}$ \\
\hline 6 & 75 & 37 & $\mathrm{~F}$ & Idiopathic & 6 & Yes & 2 & $14 \times 8$ & Resolved, 29 days \\
\hline 7 & 28 & 26 & M & $\begin{array}{l}\text { Alcohol } \\
\text { induced }\end{array}$ & 0 & Yes & 15 & $9.5 \times 6$ & Decreased, 34 days \\
\hline 8 & 64 & 25 & M & Gallstone & 3 & No & 3 & $17.8 \times 10$ & $\begin{array}{l}\text { No resolution } \\
\text { Resolved after VARD }\end{array}$ \\
\hline
\end{tabular}

\section{Results}

Endoscopic pancreatic necrosectomy with cap assistance was performed on eight patients during 2017 and 2018. Patient details and demographics are outlined in $>$ Table 1 . Median age was 64.5 years (range $26-77$ ). Contrast CT scan was obtained between the initial percutaneous or trans-gastric access and first endoscopic necrosectomy. The complex WOPN had a median length of $9.5 \mathrm{~cm}$ (range $3.2-17.8$ ) and width of $5.8 \mathrm{~cm}$ (range 2.8 -11.6). Five of eight patients were being treated for infected WOPN prior to their trans-gastric access. Median duration of endoscopic debridement was 69 minutes (range 21 105). Six of eight patients underwent a second debridement with a median duration of 61 minutes (range 16-108) ( $>$ Table 2). No periprocedural adverse events (AEs) occurred. In four of eight patients, the LAMS stent migrated out while pulling large pieces of necrosum and required replacement in the same cyst-gastrostomy tract using a non-cautery-enhanced $15 \mathrm{~mm} \times 10 \mathrm{~mm}$ LAMS. No recurrence of pancreatic fluid collection requiring endoscopic or percutaneous intervention occurred during the 6 months follow-up for seven of the eight patients. Patient 8 developed persistent necrosis resulting in an enterovesicular fistula that required an additional percutaneous drainage followed by a video-assisted retroperitoneal debridement. Patient five was the only patient with residual fluid collection on post-procedure $\mathrm{CT}$, however, no interven- tions were performed. All cyst gastrostomy LAMS were removed without AEs.

\section{Discussion}

One of the essential pitfalls of endoscopic necrosectomy is the time-consuming nature of the procedure and the need for multiple endoscopic interventions. The median number of endoscopic sessions ranged from one to five in previously published series. [5,13-15] Precise reporting of the duration of individual procedures was provided in two large multicenter series by Yasuda et al. and Gardner et al., who reported median procedure times of 63 and 68 minutes, respectively (range 25-179) $[15,16]$.

The technical advantages of cap-assisted necrosectomy resulted in clinical and radiographical resolution for $75 \%$ of patients. We believe that the reason why this technique provides a significant component of safety to the procedure is because application of suction to the WOPN from within the LAMS only suctions necrotic material and not viable tissue into the cap, thereby only removing the necrosum. In addition, the cap protects the lattice of the stent from endoscopic instruments, which decreases the likelihood of dislodging the stent during the necrosectomy. Use of the banding cap had enough length to accommodate an adequate amount of tissue, which enabled the snare or the forceps to grab a large portion of the necrosum. However, the currently used banding cap does have a 
- Table 2 Details of percutaneous and endoscopic therapy

\begin{tabular}{|c|c|c|c|c|c|c|c|c|c|}
\hline $\begin{array}{l}\text { Pa- } \\
\text { tient }\end{array}$ & $\begin{array}{l}\text { Transgastric or } \\
\text { transabdominal } \\
\text { drainage prior } \\
\text { to necrosectomy }\end{array}$ & $\begin{array}{l}\text { Necrosec- } \\
\text { tomy at } \\
\text { first drain- } \\
\text { age proce- } \\
\text { dure (yes, } \\
\text { no) }\end{array}$ & $\begin{array}{l}\text { Duration } \\
\text { of endo- } \\
\text { scopic } \\
\text { proce- } \\
\text { dure } 1 \\
\text { (minutes) }\end{array}$ & $\begin{array}{l}\text { Interval } \\
\text { between } \\
\text { debride- } \\
\text { ment } 1 \\
\text { and } 2 \\
\text { (days) }\end{array}$ & $\begin{array}{l}\text { Duration } \\
\text { of endo- } \\
\text { scopic } \\
\text { proce- } \\
\text { dure } 2 \\
\text { (minutes) }\end{array}$ & $\begin{array}{l}\text { Interval } \\
\text { between } \\
\text { debride- } \\
\text { ment } 2 \\
\text { and } 3 \\
\text { (days) }\end{array}$ & $\begin{array}{l}\text { Duration } \\
\text { of endo- } \\
\text { scopic } \\
\text { proce- } \\
\text { dure } 3 \\
\text { (minutes) }\end{array}$ & $\begin{array}{l}\text { Interval } \\
\text { between } \\
\text { debride- } \\
\text { ment } 3 \\
\text { and } 4 \\
\text { (days) }\end{array}$ & $\begin{array}{l}\text { Duration } \\
\text { of endo- } \\
\text { scopic } \\
\text { proce- } \\
\text { dure } 4 \\
\text { (minutes) }\end{array}$ \\
\hline 1 & Transabdominal & Yes & 71 & 3 & 104 & & & & \\
\hline 2 & Transgastric & No & 105 & 4 & 20 & & & & \\
\hline 3 & Transgastric & No & 81 & & & & & & \\
\hline 4 & Transgastric & No & 66 & 23 & 108 & & & & \\
\hline 5 & Transgastric & No & 21 & & & & & & \\
\hline 6 & Transgastric & No & 41 & 6 & 86 & & & & \\
\hline 7 & Transgastric & No & 10 & 2 & 21 & 7 & 59 & & \\
\hline 8 & Transgastric & Yes & 66 & 3 & 36 & 4 & 66 & 16 & 36 \\
\hline
\end{tabular}

ledge on the flare, and it is unclear whether this ledge catches onto the stent to displace it or if it is the larger piece of necrosum that pushes the stent out.

The authors understand that banding caps are approved for single use only, but due to lack of necrosectomy tools, the caps were used after adequate sterilization. Major limitations of this descriptive study beyond those inherent in retrospective investigations is the low sample size and variation in the timing of the post-procedure imaging.

\section{Conclusion}

This novel technique of cap-assisted necrosectomy gives endoscopists a new tool for performing pancreatic necrosectomies. Future prospective studies are needed to establish the clinical and economical benefit of cap-assisted pancreatic necrosectomy.

\section{Competing interests}

None

\section{References}

[1] Peery AF, Crockett SD, Barritt AS et al. Burden of gastrointestinal, liver, and pancreatic diseases in the united states. Gastroenterology 2015; 149: 1731 - 1741.e3

[2] van Dijk SM, Hallensleben NDL, van Santvoort HC et al. Acute pancreatitis: Recent advances through randomised trials. Gut 2017; 66: 2024-2032

[3] van Brunschot S, Bakker OJ, Besselink MG et al. Treatment of necrotizing pancreatitis. Clin Gastroenterol Hepatol 2012; 10: 1190-1201
[4] van Santvoort HC, Bakker OJ, Bollen TL et al. A conservative and minimally invasive approach to necrotizing pancreatitis improves outcome. Gastroenterology 2011; 141: 1254 - 1263

[5] Baron TH, Thaggard WG, Morgan DE et al. Endoscopic therapy for organized pancreatic necrosis. Gastroenterology 1996; 111: 755 - 764

[6] Seifert H, Wehrmann T, Schmitt T et al. Retroperitoneal endoscopic debridement for infected peripancreatic necrosis. Lancet 2000; 356: $653-655$

[7] ASGE Standards of Practice Committee. Muthusamy VR, Chandrasekhara $V$ et al. The role of endoscopy in the diagnosis and treatment of cystic pancreatic neoplasms. Gastrointest Endosc 2016; 84: 1 - 9

[8] Sarkaria S, Sethi A, Rondon C et al. Pancreatic necrosectomy using covered esophageal stents: A novel approach. J Clin Gastroenterol 2014; 48: 145 - 152

[9] Parikh PY, Pitt HA, Kilbane M et al. Pancreatic necrosectomy: North american mortality is much lower than expected. J Am Coll Surg 2009; 209: 712 - 719

[10] van Brunschot S, van Grinsven J, van Santvoort HC et al. Endoscopic or surgical step-up approach for infected necrotising pancreatitis: A multicentre randomised trial. Lancet 2018; 391: 51 - 58

[11] Puri N, Graham RA. Cap-assisted necrosectomy: A novel technique increasing safety and efficiency. VideoGIE 2017; 2: 260-261

[12] Charlson ME, Pompei P, Ales KL et al. A new method of classifying prognostic comorbidity in longitudinal studies: development and validation. J Chronic Dis 1987; 40: $373-383$

[13] Schmidt PN, Novovic S, Roug S et al. Endoscopic, transmural drainage and necrosectomy for walled-off pancreatic and peripancreatic necrosis is associated with low mortality-a single-center experience. Scand J Gastroenterol 2015; 50: 611-618

[14] Dhir V, Adler DG, Dalal A et al. Early removal of biflanged metal stents in the management of pancreatic walled-off necrosis: A prospective study. Endoscopy 2018; 50: 597 - 605

[15] Yasuda I, Nakashima M, Iwai T et al. Japanese multicenter experience of endoscopic necrosectomy for infected walled-off pancreatic necrosis: The JENIPaN study. Endoscopy 2013; 45: 627-634

[16] Gardner TB, Coelho-Prabhu N, Gordon SR et al. Direct endoscopic necrosectomy for the treatment of walled-off pancreatic necrosis: results from a multicenter U. S. series. Gastrointest Endosc 2011; 74: $718-726$ 